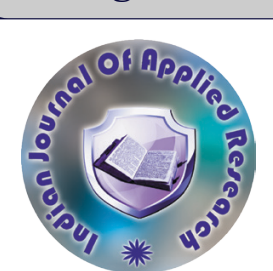

Dr. U. L. Bhuvaneswari*
Psychology

\section{TEST ANXIETY AND EDUCATIONAL ADJUSTMENT OF COLLEGE STUDENTS}

\section{ABSTRACT}

Students in their college years confront many obstacles. One of the main problems they face is how to deal with anxiety especially study anxiety, which in turn affect their adjustment to college (Vitasari, Wahab, Othman, Herawan and Sinnadurai, 2010). Hence, the present study was done to find the differences in Test anxiety and Educational adjustment of the Engineering students and arts students and to find the relationship between them. Using purposive sampling, 70 students [35 arts and 35 engineering] were selected. Test Anxiety Scale and Educational Adjustment sub-scale of the Adjustment inventory for college students by Sinha and Singh were the tools used. It was found that None of the students had Excellent Education Adjustment. $50 \%$ of the sample had Unsatisfactory Educational Adjustment and $11 \%$ of the sample had very unsatisfactory adjustment. The mean differences in Educational adjustment $(\mathrm{t}=0.248)$ and Test Anxiety ( $\mathrm{t}=0.635)$ of the Engineering and Arts students was not statistically significant. Very High Anxiety was present in $7 \%$ of the samples and $13 \%$ had High Anxiety. Moderate Anxiety was found in 40\% and low Anxiety in 4\% of the sample. The correlation between Educational Adjustment and Test Anxiety ( $\mathrm{r}=-0.04489)$ indicated a weak and non-significant negative correlation.

KEYWORDS : Test Anxiety, Educational Adjustment, Engineering, Arts Students.

Of late, the psychological impact of the educational process on adolescent's life has become a topic of raising attention. Whether being an interim form of anxiety before critical final exams or a daily hassle, students experience stressors like inefficient study before exam, lack of review of study materials, negative irrational concerns about exam, study nights and other socio-emotional factors, which may causatively or indirectly correlate with psychological problems like anxiety, depression or other forms of maladjustments (Burks and Martin, 1985; Singh and Jha, 2013; Hashmat, Hashmat, Amanullah and Aziz, 2008). In the modern-day context of high-stakes testing, it has become increasingly important to understand the relationship between test anxiety and test performance (e.g., Cizek and Burg, 2006; Von der Embse and Hasson, 2012). The adjustments that the college students face is varied and complex: academic demands in a new learning environment, new social circles, embarking on a future career path, to name a few. Within the new environment, the student will learn to show greater personal independence and responsibility (UCLA-Parents and Family Association, 2019).

No matter what his or her expectations, nearly all students encounter obstacles he or she didn't anticipate during the transition to college. Even positive life changes produce stress, and certainly the changes can lead to feelings of sadness, loneliness and worry. Hence, the present study was done to find the differences in Test anxiety and Educational adjustment of the Engineering students and arts students and to find the relationship between Test anxiety and Educational adjustment. Using purposive sampling, 70 students [35 arts and 35 engineering] were selected. Personal Data Sheet, Test Anxiety Scale and Educational Adjustment sub-scale of the Adjustment inventory for college students by Sinha and Singh were the tools used. A single group pre- test design was used in this study.

\section{RESULTS AND DISCUSSION}

TABLE I LEVEL OF EDUCATIONAL ADJUSTMENT OF THE SAMPLE

\begin{tabular}{|l|c|c|}
\hline \multicolumn{1}{|c|}{ Level of Educational Adjustment } & Number & Percentage \\
\hline EXCELLENT & - & - \\
\hline GOOD & 8 & 11 \\
\hline AVERAGE & 19 & 28 \\
\hline UNSATISFACTORY & 35 & 50 \\
\hline VERY UNSATISFACTORY & 8 & 11 \\
\hline
\end{tabular}

It is seen that $11 \%$ of the samples experienced Good Educational Adjustment. Average educational adjustment was found in $28 \%$ of the sample. $50 \%$ of the sample had Unsatisfactory Educational Adjustment and $11 \%$ of the sample had very unsatisfactory adjustment. They seemed to have very little interest in study. These people were lazy and had low concentration level. They were disturbed easily with their academic requirement.
TABLE II MEAN DIFFERENCE IN EDUCATIONAL ADJUS TMENT OF THE ENGINEERING AND ARTS STUD ENTS

\begin{tabular}{|c|c|c|c|}
\hline GROUP & MEAN & STANDARD DEVIATION & t-value \\
\hline $\begin{array}{c}\text { Engineering } \\
\text { students }\end{array}$ & 9.88 & 3.14 & $\begin{array}{c}0.248 \text { Not } \\
\text { Significant }\end{array}$ \\
\hline Arts students & 8.91 & 3.61 & \\
\hline
\end{tabular}

The mean Educational adjustment of the Engineering students was 9.88, whereas, for the Arts students, it was 8.91. The calculated t-value was 0.248 . Though there was a slight difference in the mean value of the two groups, it was not statistically significant.

TABLE III TEST ANXIETY OF THE SAMPLE [N=70]

\begin{tabular}{|c|c|c|}
\hline Level of Test Anxiety & Number & Percentage \\
\hline VERY HIGH & 5 & 7 \\
\hline HIGH & 9 & 13 \\
\hline MODERATE & 28 & 40 \\
\hline LOW & 3 & 4 \\
\hline VERY LOW & 25 & 36 \\
\hline
\end{tabular}

It is disheartening to see that $7 \%$ of the samples had Very High Anxiety and $13 \%$ of the samples had High Anxiety. They seemed to be in a constant state of worry and anxiousness. Though it is common for the students to worry more about things like tests and exams, the result of this students seemed to be alarming as they appeared to worry excessively about routine events. Moderate Anxiety was found in $40 \%$ of the sample and low Anxiety was reported by $4 \%$ of the sample.

TABLE IV MEAN DIFFERENCE IN TEST ANXIETY OF ENGINEERING AND ARTS COLLEGE STUDENTS

\begin{tabular}{|c|c|c|c|}
\hline Group & Mean & Standard Deviation & t-value \\
\hline $\begin{array}{c}\text { Engineering } \\
\text { Students }\end{array}$ & 68.62 & 9.94 & $\begin{array}{c}0.635 \text { Not } \\
\text { Significant }\end{array}$ \\
\hline Arts Students & 69.88 & 12.20 & \\
\hline
\end{tabular}

The mean Test Anxiety of the engineering students was 68.62 and that of the Arts students was 69.88 . Though there seemed to be a slight difference in the mean test anxiety of the two groups, the calculated tvalue 0.635 , indicated no statistical difference.

TABLE V CORRELATION BETWEEN EDUCATIONAL ADJUSTMENT AND TEST ANXIETY OF THE SAMPLE

\begin{tabular}{|c|c|c|c|}
\hline Variables & Mean & Standard deviation & r-value \\
\hline $\begin{array}{c}\text { Educational } \\
\text { adjustment }\end{array}$ & 9.4 & 3.39 & $\begin{array}{c}-0.04489 \\
\text { Not Significant }\end{array}$ \\
\hline Test anxiety & 69.25 & 11.06 & \\
\hline
\end{tabular}

The mean Educational Adjustment of the sample was 9.14. The mean test anxiety of the sample was 69.25 . The calculated correlation value indicated a weak and negative correlation, which was not statistically significant. 


\section{MAJOR FINDINGS}

None of the students had Excellent Education Adjustment. 50\% of the sample had Unsatisfactory Educational Adjustment and $11 \%$ of the sample had very unsatisfactory adjustment. The mean differences in Educational adjustment $(\mathrm{t}=0.248)$ and Test Anxiety $(\mathrm{t}=0.635)$ of the Engineering and Arts students was not statistically significant. Very High Anxiety was present in $7 \%$ of the samples and $13 \%$ of the samples had High Anxiety. Moderate Anxiety was found in $40 \%$ and low Anxiety in $4 \%$ of the sample. The correlation between Educational Adjustment and Test Anxiety ( $\mathrm{r}=-0.04489)$ indicated a weak and nonsignificant negative correlation.

\section{CONCLUSION}

Test anxious students have difficulties in their daily adjustment or may have some effect of test anxiety on their educational adjustment. Welladjusted students also may have low test anxiety. As there is little research made available on this area, the present researcher assumed that there may be a relation between the two variables. Therefore, it is very crucial to know the nature of the relation between test anxiety and adjustment of the students in terms of their stream of study, gender and locality.

\section{REFERENCES}

1. Burks, N. and Martin, B. (1985). Everyday problems and life change events: Ongoing Burks, N. and Martin, B. (1985). Everyday problems and life change
versus acute sources of stress. Journal of Human Stress. 11(1):27-3.

2. Cizek, G. J. and Burg, S. S. (2006). Addressing test anxiety in a high-stakes environment. Thousand Oaks, California: Corwin Press.

3. Singh, I. and Jha, A. (2013). Anxiety, optimism and academic achievement among students of private medical and engineering colleges: a comparative study. Journal of Educational and Developmental Psychology. 3(1):222.

4. Hashmat, S., Hashmat, M., Amanullah, F. and Aziz, S. (2008). Factors causing exam anxiety in medical students. Journal-Pakistan Medical Association. 58(4): 16

5. UCLA-Parent and Family Association (2019). First year Parents and Families. https://parents.ucla.edu/support-your-student/first-year-parents-families/

6. Vitasari, P., Abdul Wahab, M. N., Othman, A., Herawan, T. and Sinnadurai, S. K. (2010). The relationship between study anxiety and academic performance among engineering students. Procedia Social and Behavioral Sciences 8, 490-497. http://dx.doi.org $/ 10.1016 /$ j.sbspro.2010.12.067

7. Von Der Embse, N. and Hasson, R. (2012). Test anxiety and high-stakes test performance between school settings: Implications for Educators. Preventing School Failure, 56, 180-187. 